\title{
RESPON MASYARAKAT TERHADAP KEBIJAKAN PEMBEBASAN NARAPIDANA DALAM RANGKA PENANGGULANGAN PENYEBARAN CORONA VIRUS COVID-19 DI DUSUN PUNJUL DESA PUNJUL KECAMATAN KARANGREJO KABUPATEN TULUNGAGUNG (Community Response To The Convict's Liberation Policy In Order To Countermeasure The Covid-19 In Punjul Hamlet Punjul Village Karangrejo Subdistrict Tulungagung District)
}

\author{
Hasim Asngari, Padmono Wibowo \\ Program Studi Manajemen Pemasyarakatan, Politeknik IImu Pemasyarakatan, \\ Badan Pengembangan Sumber Daya Manusia, Depok \\ hasimasyarie@gmail.com
}

Tulisan Diterima: 09-02-2021; Direvisi: 31-05-2021; Disetujui Diterbitkan: 11-06-2021

DOI: http://dx.doi.org/10.30641/kebijakan.2021.V15.165-180

\begin{abstract}
ABSTRAK
Wabah virus corona (Covid-19) yang sedang melanda dunia pada dewasa ini, hal tersebut bukan suatu wabah yang dianggap remeh atau diabaikan begitu saja. Implementasi kebijakan pemerintah terkait pembebasan narapidana melalui program integrasi dan program asimilasi adalah wujud upaya dalam menanggulangi penyebaran corona virus Covid-19 pada lembaga pemasyarakatan, lembaga pembinaan khusus anak, maupun rumah tahanan negara. Tujuan penelitian ini adalah mengetahui respon masyarakat mengenai kebijakan pembebasan narapidana guna penanggulangan penyebaran covid-19 di RT 022 RW 006 Dusun Punjul Desa Punjul Kecamatan Karangrejo Kabupaten Tulungagung yang dilihat dari tiga dimensi yaitu afektif, kognitif, dan konatif. Metode penelitian ini menggunakan pendekatan kuantitatif deskriptif dengan populasi yang berjumlah 102 orang , diambil sampel secara acak sejumlah 42 responden. Menggunakan angket skala Likert dalam teknik pengumpulan data. Berdasarkan hasil analisis diketahui bahwa masyarakat memiliki kognitif yang cukup terhadap kebijakan pembebasan narapidana dengan nilai mean sebesar 2,96, Afektif sebesar 2,83, Konatif sebesar 3,83. Kemudian disimpulkan dari ketiga dimensi tersebut menjadi suatu respon masyarakat dengan nilai mean sebesar 3,20 dan diperlukan suatu sosialisasi terhadap masyarakat terkait kebijakan pembebasan narapidana.
\end{abstract}

Kata kunci: respon masyarakat; kebijakan pembebasan narapidana; Covid-19.

\begin{abstract}
The coronavirus (Covid-19) outbreak that is sweeping the world today, it is not an outbreak that is taken lightly or ignored. Implementation of government policy regarding convict exemption through assimilation program and integration program is a form of effort in tackling the spread of Corona Covid-19 virus in correctional institution, special development Institutions for children, and state detention houses. The purpose of this research is to know the community response to the convict's liberation policy in order to countermeasure the spread of Corona virus Covid-19 in RT 022 RW 006 in Punjul, Karangrejo, Tulungagung which is viewed from three dimensional cognitive, affective, and conative. The study method used a descriptive quantitative approach with a population amounting to 102 people, randomly sampled a number of 42 respondents. The data collection techniques use the Likert scale. Based on the analysis results it is known that the community has sufficient cognitive response to the convict exemption policy with a mean value of 2.96, affective 2.83 , conative 3.83.
\end{abstract}


Then deduced from these three dimensions into a community response with a mean value of 3.20 and a socialization is needed to the community regarding the policy of inmate release.

\section{Keywords : community response; convict's liberation policy; Covid-19.}

\section{PENDAHULUAN}

\section{Latar Belakang}

Coronavirus merupakan sekumpulan virus yang dapat menyebabkan infeksi pada saluran pernapasan dari flu biasa hingga penyakit yang sifatnya sangat parah contohnya: sindrom pernapasan timurtengah (MERS-CoV), sindrom pernafasan akut parah (SARS-CoV). ${ }^{1} \quad$ Dalam penelitian yang dilakukan oleh Jimmy Whitworth yang berjudul "COVID-19: A Fast Evolving Pandemic" menjelaskan dimana terdapat dugaan mengenai virus ini bahwa pertama kali menular melalui hewan ke manusia, lalu diketahui virus ini dapat menularkan melalui antar manusia dari individu satu ke individu lainnya. Hingga sekarang, vaksin masih dalam proses tahap uji coba guna mencegah terjadi infeksi virus dan sekarang secara resmi oleh WHO disebut Corona virus disease 2019 (Covid-19). ${ }^{2}$ Kemudian dijelaskan juga dalam Keputusan Menteri Kesehatan Republik Indonesia Nomor HK.01.07/MENKES/382/2020 menjelaskan bahwa virus Covid-19 dapat menular masuk ke dalam tubuh melalui hidung, mulut, dan juga bisa melalui mata.

Wabah virus corona (Covid-19) yang sedang melanda dunia pada dewasa ini, hal tersebut bukan suatu wabah yang dianggap remeh atau diabaikan begitu saja. Apalagi melihat kasus di Negara India

1 Aisha M. Al-Osail and Marwan J. Al-Wazzah, "The History and Epidemiology of Middle East Respiratory Syndrome Corona Virus," Multidisciplinary Respiratory Medicine 12, no. 1 (2017).

2 Jimmy Whitworth, "COVID-19: A Fast Evolving Pandemic," Transactions of the Royal Society of Tropical Medicine and Hygiene 114, no. 4 (2020): 227-228. dewasa ini yang terjadi Tsunami Covid-19. ${ }^{3}$ Mungkin awalnya saat melihat dari gejala virus corona, akan berasumsi bahwa sakit ini hanyalah sebatas flu biasa, namun bagi analisis kedokteran Covid-19 merupakan virus yang cukup berbahaya dan mematikan seperti dalam New delhi India tsunami covid kasus harian mencapai 300ribu dan hingga kini dalam data 29 April 2021 tercatat positif Covid-19 mencapai 18,3 Juta warga dan 204 ribu kematian karena terinfeksi virus. ${ }^{4}$ Dalam perkembangan di tahun 2021, penularannya masih sangat signifikan dikarenakan penyebarannya sangat cepat hingga beberapa negara di dunia merasakan dampaknya termasuk di Indonesia yang kini mulai ditemukan corona varian baru.

Upaya pemerintah Indonesia untuk mencegah dan menanggulangi Covid-19 yang telah ditetapkan sebagai bencana nasional non-alam dan pandemi global dengan pemberlakuan kepada seluruh masyarakat mengenaikebijakan-kebijakan yang mengatur tentang antisipasi dan upaya mengurangi jumlah kasus terkonfirmasi virus corona. Salah satunya seperti penerapan kebijakan physical distancing dapat diartikan sebagai jaga jarak ataupun jaga jarak aman seperti dalam keputusan menkes republik indonesia Nomor HK.01.07/MENKES/328/2020 pencegahan Covid-19 pada situasi pandemi bahwa jaga jarak antar orang minimal satu meter dan Peraturan menteri kesehatan RI Nomor 9 Tahun 2020 menjelaskan bahwa pengangan virus corona atau Covid-19 harus dilakukan pembatasan sosial untuk menekan laju peningkatan jumlah terpapar virus.

$3 \quad$ Tommy Patrio Sorongan, "Tsunami Corona India Bahaya Besar bagi Dunia Ini Alasannya," CNBC Indonesia.

$4 \quad$ Ibid 
Dalam pelaksanaannya dimana pemerintah indonesia bisa menerapkan langkah-langkah dalam menegakkan peringatan kesehatan. Kebijakan yang ditetapkan oleh pemerintah tidak lain guna kepentingan masyarakat. Sebuah kebijakan publik merupakan kegiatan pemerintah guna mencapai suatu tujuan tertentu dan mencapai hasil akhir. Kesalahan atau kekurangan dari kebijakan tersebut hanya akan terasa pasca dilaksanakan. Lalu keberhasilan dari semua pelaksanaan mampu ditinjau dari seberapa besar efek yang dirasakan ataupun ditimbulkan. ${ }^{5}$

\section{Penerapan physical distancing} dalam keputusan menkes republik indonesia Nomor HK.01.07/MENKES/328/2020 untuk hal ini terkendala pada institusi tertentu seperti LPKA, LAPAS, dan RUTAN adalah institusi tertutup yang mempunyai hunian tingkat tinggi dan tercatat jumlah Narapidana maupun Tahanan di seluruh LAPAS, LPKA, dan RUTAN di Indonesia berdasarkan data direktorat jenderal pemasyarakatan per 30 April 2021 total 262.480 orang maka sangat rentan terhadap penularan dan penyebaran corona virus Covid-19 dan sangat sulit menerapkan physical distancing.

Pencegahan terhadap persebaran penyakit harus dilakukan karena narapidana memiliki hak layanan kesehatan yang bisa berupa pengobatan dan pencegahan. ${ }^{6}$ Supaya seluruh penghuni penjara di Indonesia tidak terjangkit corona virus Covid-19 maka langkah cepat yang dilakukan Menkumham Yasonna H. Laoly mengeluarkan kebijakan terkait pengeluaran narapidana. Berdasarkan pada Permenkumham No. 10 tahun 2020

$5 \quad$ Asep Taufik Rohman, "Implementasi Kebijakan Melalui Kualitas Pelayanan Penerimaan Pajak Daerah Dan Implikasinya Terhadap Kepuasan Masyarakat Di Dinas Pendapatan Kabupaten Kuningan" (Bandung: Universitas Pasundan, 2016).

6 Ahmad Sanusi, "Aspek Layanan Kesehatan Bagi Warga Binaan Pemasyarakatan Dan Tahanan Di Lembaga Pemasyarakatan," Jurnal IImiah Kebijakan Hukum 10, no. 1 (2016): 1-29. tentang hak integrasi dan pemberian asimilasi narapidana dan anak dalam pencegahan melalui program asimilasi serta penanggulangan Corona virus di Lapas/ LPKA/Rutan di Indonesia. Berdasarkan Keputusan Menkumham pada Nomor M.HH-19.PK.01.04.04 Tahun 2020 tentang Pengeluaran dan Pembebasan Narapidana dan Anak. Kebijakan ini sebagai upaya pemerintah dalam penyelamatan pada warga binaan dengan dilakukan pembebasan dan pengeluaran melalui program asimilasi berdasarkan data yang telah disampaikan oleh kabag humas Ditjenpas Kemenkumham Rika Aprianti di Jakarta per 20 April 2020 pada 07.00 WIB sekitar 36.641 orang dan program integrasi sekitar 2.181 orang. ${ }^{7}$ Dengan program asimilasi dan integrasi juga bisa menjadi solusi alternatif dalam mengurangi overcrowded baik di Lapas maupun Rutan. ${ }^{8}$ Jadi persebaran virus di dalam Lapas dan Rutan akan dapat semakin ditekan dengan adanya pembebasan narapidana melalui program asimilasi dan integrasi.

Respon masyarakat terkait narapidana yang dikeluarkan dan dibebaskan hasil dari pelaksanaan kebijakan penanggulangan corona virus Covid-19 di LPKA, LAPAS, dan RUTAN sekarang adalah kurang setuju dan disertai ketakutan akan kejahatan yang terulang kembali dilakukan oleh napi karena masih memiliki stigma buruk di kalangan masyarakat walaupun narapidana tersebut sudah selesai menjalani masa pidananya. Masyarakat sebenarnya menyadari bahwasannya narapidana merupakan terpidana yang menjalani pidana hilang kemerdekaan pada lembaga pemasyarakatan. ${ }^{9}$ Diharapkan mantan

7 Fathur Rohman, “38.822 Napi Dan Anak Dikeluarkan Dari Lapas Cegah Pandemi COVID-19," Antaranews.

8 Ahmad Jazuli, "Pembentukan Satuan Kerja Baru Pemasyarakatan Sebagai Solusi Alternatif Mengatasi Overcrowded," Jurnal IImiah Kebijakan Hukum (2021).

9 Permenkumham No. 10 Tahun 2020 Tentang 
narapidana tersebut tidak akan mengulangi tindak kejahatan lagi setelah keluar dari lembaga pemasyarakatan, hal ini dikarenakan selama menjalani pidananya di balik jeruji mereka mendapatkan pembinaan baik rohani maupun jasmani, diberi keterampilan kerja, dan diberi pengarahan hidup yang lebih baik agar bisa menyesuaikan diri kembali di tengah-tengah masyarakat. Tetapi pada kenyataannya tidak sesederhana itu, justru sebagian dari mantan napi cenderung melakukan tindak pidana lagi. Hal tersebut disebabkan adanya beberapa aspek, salah satunya stigma sosial dari masyarakat. Mantan narapidana seringkali dinilai masyarakat tidak akan berubah, dilabel dengan sesuatu yang sifatnya negatif, seringkali selalu dicurigai, bahkan dipinggirkan dan sampai pada penghinaan. ${ }^{10}$

Begitu juga dengan penelitian sejenis oleh Lila Afrida Pebriana dalam jurnal Legal Standing : Jurnal IImu Hukum yang berjudul "Kontra Masyarakat Terhadap Meningkatnya Kriminalitas Pasca Asimilasi Narapidana Dampak Covid-19", bahwa dalam penelitiannya terdapat respon masyarakat yaitu aspek yang pertama terkait respon negatif akan dibebaskannya narapidana dalam mencegah dan memutus rantai penyebaran corona virus Covid-19 dan aspek yang kedua terkait kekhawatiran masyarakat terhadap fakta lapangan yang menunjukkan peningkatan terhadap angka kejahatan setelah diterapkan kebijakan tersebut yang dimana gangguan kamtib masyarakat meningkat sebesar $38,45 \%$ yang didominasi kasus pencurian yang mengalami kenaikan sebesar $68,61 \%$, kasus kedua yaitu

Syarat Pemberian Asimilasi Dan Hak Integrasi Bagi Narapidana Dan Anak Dalam Rangka Pencegahan Melalui Program Asimilasi Dan Penanggulangan Penyebaran Covid-19 (Republik Indonesia, 2020).

10 Wanda Fitri, "Perempuan Dan Perilaku Kriminalitas: Studi Kritis Peran Stigma Sosial Pada Kasus Residivis Perempuan," Kafa'ah: Journal of Gender Studies 7, no. 1 (2017): 67. kasus penggelapan mengalami kenaikan sebesar $242,71 \%$, dan tidak hanya itu masih ada kasus narkoba yang semakin meningkat sebesar $14,48 \%$, selanjutnya kasus perjudian yang mengalami kenaikan sebesar $100 \%$ dan terakhir kasus pencurian bermotor mengalami kenaikan sebesar 98,25\%. Dengan itu masyarakat semakin kontra terhadap kebijakan ini karena kejahatan semakin meningkat, aktivitas masyarakat dihantui dengan rasa khawatir atas kejahatan yang dilakukan ditambah dengan permasalahan baru yaitu terjadi banyaknya pengangguran. ${ }^{11}$

Berdasarkan beberapa temuan fenomena diatas, maka penulis tertarik untuk mengangkat permasalahan dalam penelitian ini yang berjudul "Respon Masyarakat Terhadap Kebijakan Pembebasan Narapidana Dalam Rangka Penanggulangan Penyebaran Corona Virus Covid-19 di Dusun Punjul Desa Punjul Kecamatan Karangrejo Kabupaten Tulungagung ".

\section{Rumusan Masalah}

Bagaimana respon masyarakat terhadap kebijakan pembebasan narapidana dalam rangka penanggulangan penyebaran corona virus Covid-19 di Dusun Punjul Desa Punjul Kecamatan Karangrejo Kabupaten Tulungagung?.

\section{Tujuan}

Untuk mengetahui respon masyarakat terhadap kebijakan pembebasan narapidana dalam rangka penanggulangan penyebaran corona virus Covid-19 di Dusun Punjul Desa Punjul Kecamatan Karangrejo Kabupaten Tulungagung.

11 Lila Afrida Pebriana, "Kontra Masyarakat Terhadap Meningkatnya Kriminalitas Pasca Asimilasi Narapidana Dampak Covid-19," Legal Standing : Jurnal IImu Hukum 4, no. 2 (2020). 


\section{Metode Penelitian}

\section{Pendekatan}

Metode penelitian yang digunakan dalam penelitian ini adalah pendekatan kuantitatif. Alasan mendasar peneliti menggunakan pendekatan ini untuk mendapatkan hasil data yang akurat, terpercaya, realitas dan dapat dipertanggungjawabkan kebenarannya. Dalam Rangka Penanggulangan Penyebaran corona virus Covid-19, maka dari itu peneliti ingin melihat hubungan variabel yang diteliti apakah variabel tersebut memiliki hubungan sebab dan akibat. ${ }^{12}$

\section{Metode Pengumpulan Data}

Teknik pengambilan data melalui penyebaran kuesioner atau angket kepada masyarakat RT 022 RW 006, Desa Punjul, Kecamatan Karangrejo Kabupaten Tulungagung yang mempunyai kartu tanda penduduk dan tinggal menetap. Kemudian untuk penunjang data yang tidak dapat diperoleh dalam angketdengan menggunakan teknik wawancara, observasi.

\section{Teknik Penarikan Sampel}

Populasi merupakan subjek dengan memiliki karakteristik tertentu dan kuantitas yang telah ditetapkan oleh peneliti guna dipelajari atau suatu wilayah generalisasi yang terdiri dari objek, lalu ditarik kesimpulan. ${ }^{13}$ Populasi dalam penelitian ini menggunakan populasi dari masyarakat RT 022 RW 006, Desa Punjul, Kecamatan Karangrejo Kabupaten Tulungagung yang mempunyai kartu tanda penduduk dan tinggal menetap pada masa penelitian berjumlah 102 jiwa (Sumber : Kepala Rukun Tetangga 022, RW 006, Desa Punjul, Kecamatan Karangrejo, Kabupaten Tulungagung/ Mei 2020). Menggunakan Teknik sampling pada penelitian tersebut merupakan teknik Probability Sampling. Yang mana teknik

12 Sugiyono, Metode Penelitian Kuantitatif, Kualitatif, Dan R\&D (Bandung: Alfabeta, 2016).

13 Sugiyono, Metode Penelitian Administrasi (Bandung: CV Alfabeta, 2002). tersebut pengambilan sampel memberikan peluang dan kesempatan sama pada setiap unsur populasi untuk dipilih menjadi anggota sampel. Selanjutnya dari teknik tersebut peneliti menggunakan metode Simple Random Sampling, dengan mengambil satu sampel pada setiap kartu keluarga secara acak, maka peneliti menjadikan seluruh anggota menjadi sampel dengan responden sebanyak 42 orang.

\section{Teknik Analisa Data}

Teknik analisis data dalam penelitian ini menggunakan analisis statistik deskriptif, yang dimana penelitian ini menguji secara nyata digunakan untuk mengetahui secara rinci responden dalam merespon kebijakan pembebasan narapidana sebagai upaya penanggulangan corona virus covid-19 dalam bentuk angka kemudian dideskripsikan kembali.

Variabel menurut Mayer adalah suatu konsep dalam bentuk konkret yang dapat dioperasionalkan dan dapat dijadikan sebagai acuan yang mudah dilakukan identifikasi, pengurutan, pengukuran, observasi, dan klasifikasi. ${ }^{14}$ Analisis model Stimulus-respon, Stimuli adalah penangkapan objek lingkungan melalui alat indera yang kemudian diubah menjadi pola tertentu yang memiliki sensasi dan memiliki sifat gambaran, pendengaran, hingga rasa. Sedangkan respon merupakan reaksi yang muncul atau efek yang timbul terhadap stimulus tertentu. ${ }^{15}$ Jadi dengan adanya kebijakan sebagai stimulus maka akan muncul suatu respon masyarakat, sehingga pada penelitian ini yang akan diteliti yaitu variabel "respon" dimana masyarakat dalam merespon kebijakan pembebasan narapidana berikut variabel serta dimensi-

14 Rachmat Kriyantono, Teknik Praktis Riset Komunikasi (Prenada Media, 2006).

15 B. Aubrey Fisher, Teori-Teori Komunikasi : Perspektif Mekanistis, Psikologis, Interaksional, Dan Pragmatis, ed. Rakhmat Jalaludin (Bandung: Remadja Karja, 1986). 
dimensi dalam definisi operasional dijelaskan sebagai berikut :

Variabel : Respon

Dimensi :

a. Kognitif àlndikator :

- Pengetahuan terhadap alasan dikeluarkan kebijakan

- Pemahaman mengenai fungsi kebijakan

- Kepercayaan terhadap efektivitas penerapan kebijakan

b. Afektif àlndikator :

- Kebijakan dapat diterima

- Sikap masyarakat dalam merespon kebijakan

- Partisipasi masyarakat dalam merespon kebijakan

- Penilaian masyarakat terhadap kebijakan

c. Konatif àlndikator :

- Perilaku nyata dalam merespon kebijakan

- Tindakan setelah diterapkan kebijakan

- Memberikan kebiasaan yang dihasilkan dari kebijakan

Data penelitian ini bersifat kuantitatif. Dalam hal ini, pengukuran data yang diperoleh menggunakan skala Likert dengan memberikan nilai atau skor pada setiap jawaban. Sebagai bentuk dari skala ordinal dimaksudkan untuk membedakan objek satu dengan objek lainnya dan untuk menentukan mana yang besar dan mana yang kecil. Pada skala likert jawaban tiap item/poin instrumen. Yang mana memiliki gradasi mulai sangat positif sampai sangat negatif. Kemudian jawaban tersebut diberi skor. ${ }^{16}$

a. Sangat setuju/selalu/sangat positif
(SS) skor 5

b. Setuju/sering/positif

(S) skor 4
C. Ragu-ragu / kadang-kadang / netral (N) skor 3

d. Tidak setuju/hampir tidak pernah / negatif (TS) skor 2

e. Sangat tidak setuju/tidak pernah / sangat negatif

(STS) skor 1

Jawaban responden yang dihasilkan akan dideskripsikan dan ditarik kesimpulan dalam merespon kebijakan pembebasan narapidana dalam rangka penanggulangan corona virus covid-19 menggunakan analisis mean. Nilai mean tersebut diperoleh dari ratarata keseluruhan skor yang telah diberikan oleh responden dan dihitung menggunakan SPSS. kemudian nilai mean tersebut diberi kriteria penilaian skala lima dikonversikan menjadi data kualitatif. ${ }^{17}$

Rumus Interval $=$ (skor tertinggi-skor terendah) / Jumlah kriteria

$$
\begin{aligned}
& =(5-1) / 5 \\
& =0,80
\end{aligned}
$$

Tabel 1. Kriteria Penilaian

\begin{tabular}{|c|c|}
\hline Interval Skor & $\begin{array}{c}\text { Kriteria } \\
\text { Penilaian }\end{array}$ \\
\hline $4,21-5$ & Sangat baik \\
\hline $3,41-4,20$ & Baik \\
\hline $2,61-3,40$ & Cukup \\
\hline $1,81-2,60$ & Kurang \\
\hline $1,00-1,80$ & Buruk \\
\hline
\end{tabular}

Sumber: Analisis Rumus Interval, 2020

\section{PEMBAHASAN}

\section{Analisis Respon}

Hasil penelitian yang didapatkan berupa respon masyarakat terhadap kebijakan pembebasan narapidana di dusun punjul desa punjul kecamatan karangrejo kabupatan tulungagung didapatkan respon masyarakat yang beragam dari segi kognitif, afektif, dan \begin{tabular}{l}
\hline 17 S.Eko Putro Widoyoko, Evaluasi Program \\
$\begin{array}{l}\text { Pembelajaran (Yogyakarta: Pustaka Belajar, } \\
\text { 2009). }\end{array}$
\end{tabular}

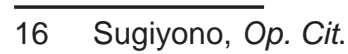


konatif terhadap kebijakan. Respon itu sendiri merupakan suatu tanggapan seseorang terhadap rangsangan atau stimulus yang sedang dihadapinya. Tanggapan tersebut terjadi setelah seseorang memerhatikan, memahami dan kemudian menerima stimulus yang datang menghampirinya. Respon itu muncul sebagai wujud dari motif yang muncul setelah seseorang melakukan penilaian terhadap obyek respon. ${ }^{18}$

Menurut Steven M. Chafferespon respon dibedakan menjadi 3 (tiga) bagian yaitu : ${ }^{19}$

1. Kognitif (cognitive): bagian pertama respon kognitif yang dimaksud adalah respon yang memiliki keterkaitan erat dengan pengetahuan, pemahaman, kepercayaan seseorang mengenai sesuatu.

2. Afektif (affective) : bagian kedua respon afektif yang dimaksud adalah respon yang memiliki keterkaitan erat dengan emosi, sikap, hingga menilai seserorang mengenai sesuatu.

3. Konatif (conative): bagian ketiga respon konatif atau psikomotorik yang dimaksud adalah respon yang memiliki keterkaitan erat dengan perilaku seseorang yang meliputi tindakan, tingkah laku, kebiasaan.

Menurut Selo Soemardjan berpendapat bahwa Masyarakat merupakan sejumlah manusia hidup bersama dan bercampur guna waktu yang cukup lama sehingga bisa menghasilkan suatu kebudayaan. ${ }^{20}$ Jadi masyarakat merupakan sekumpulan orangorang yang hidup saling berdampingan dalam kurun waktu yang relatif lama dan kemudian membentuk suatu kelompok satu

18 Bambang Suteng Sulasmono, "Respons Masyarakat Desa Terhadap Pembangunan Industri Besar Kasus Desa Hardjosari, Kecamatan Bawen, Kabupaten Semarang, Jawa Tengah" (Universitas Kristen Satya Wacana, 1994).

19 Jalaluddin Rakhmat, Metode Penelitian Komunikasi, Bandung: Remaja Rosdakarya (Bandung: PT Remaja Rosdakarya, 1999).

20 Soleman B. Taneko, Sistem Sosial Indonesia (Jakarta: Fajar Agung, 1994). kesatuan yang menimbulkan suatu kebiasaan serta menciptakan suatu sistem kehidupan bersama, dinamakan dengan kebudayaan.

Definisi kebijakan menurut Federick sebagaimana dikutip oleh Leo Agustino diartikan sebagai berikut :

"Serangkaian kegiatan atau tindakan yang diusulkan seseorang, kelompok atau pemerintah dalam suatu lingkungan tertentu dimana terdapat hambatan-hambatan dan kesempatan-kesempatan terhadap pelaksanaan usulan kebijaksanaan tersebut dalam rangka mencapai tujuan tertentu". ${ }^{21}$

Dikutip dari Harol D. Lasswell dan Abraham Kaplan tentang pengertian kebijakan negara sebagai sebuah program dalam pencapaian tujuan (a projected program of goals), nilai-nilai (values) dan praktek-praktek (and practices) yang terarak2? Pengertianpengertian tentang kebijakan berdasarkan pendapat para ahli yang telah dijabarkan diatas maka penulis dapat menyimpulkan bahwa kebijakan merupakan suatu program yang pada pelaksanaannya memiliki nilainilai untuk mencapai suatu tujuan tertentu dalam rangka mengatasi masalah yang ada di lingkungan tertentu.

Teori Stimulus-respon merupakan dasar dari disiplin ilmu psikologi yang memiliki antara proses aksi dengan reaksi yang sederhana. Antara stimulus dan respon adalah sesuatu yang tidak dapat dipisahkan karena suatu aksi akan memunculkan reaksi. Stimuli (S) adalah penangkapan objek lingkungan melalui alat indera yang kemudian diubah menjadi pola tertentu yang memiliki sensasi dan memiliki sifat gambaran, pendengaran, hingga rasa. Sedangkan response $(R)$ merupakan reaksi yang muncul atau efek yang timbul

21 Leo Agustino, Dasar-Dasar Kebijakan Publik. (Alfabeta:Bandung, 2012).

22 Siti Kurnia Rahayu, Perpajakan Indonesia : Konsep Dan Aspek Formal (Yogyakarta: Graha IImu, 2010). 
terhadap stimulus tertentu. ${ }^{23} \mathrm{Jadi}$, stimulus yang diterima oleh individu atau seseorang maka akan menimbulkan suatu reaksi yaitu respon dalam hal ini bisa berupa perubahan cara pandang, sikap, tingkah laku individu terhadap sesuatu, sehingga kedua unsur tersebut tidak dapat dipisahkan dengan alasan dimana antara stimulus dengan respon memiliki hubungan yang saling berkaitan dan respon itu sendiri dapat muncul karena efek dari adanya stimulus-stimulus yang diterima oleh seseorang.

Berikut ini model teori Stimulus-Respon $(\mathrm{S}-\mathrm{R})$ :

Gambar 1. Model Teori S-R

\section{STIMULUS}

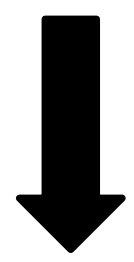

RESPON

Sumber : B. Aubrey Fisher, Teori-Teori Komunikasi : Perspektif Mekanistis, Psikologis, Interaksional, Dan Pragmatis, ed. Rakhmat Jalaludin Bandung: Remadja Karja, 1986

Upaya pemerintah untuk mencegah dan menanggulangi penyebaran virus corona atau covid-19 dengan memberikan kebijakan physical distancing kepada seluruh rakyatnya, terkecuali untuk rakyat yang menghuni di Lembaga Pemasyarakatan, Lembaga Pembinaan Khusus Anak, dan Rumah

23 B. Aubrey Fisher, Teori-Teori Komunikasi : Perspektif Mekanistis, Psikologis, Interaksional, Dan Pragmatis.
Tahanan Negara. Hal ini dikarenakan hunian yang tinggi sehingga sulit untuk melakukan phisycal distancing di dalam Lapas, LPKA, dan Rutan. Dengan alasan ini pemerintah tetap mengupayakan agar seluruh rakyatnya baik diluar atau didalam jeruji besi tetap bisa terhindar dari virus corona yaitu dengan memberikan kebijakan alternatif physical distancing di Lapas, LPKA, dan Rutan dengan mengeluarkan Permenkumham No. 10 tahun 2020 tentang syarat pemberian asimilasi dan hak integrasi bagi narapidana dan anak dalam rangka pencegahan melalui program asimilasi dan penanggulangan penyebaran Covid-19 dan kebijakan lanjutan yaitu Keputusan Menteri Hukum dan HAM Nomor M.HH-19.PK.01.04.04 Tahun 2020 tentang Pengeluaran dan Pembebasan Narapidana dan Anak. Kebijakan ini menimbulkan berbagai respon masyarakat dari segi kognitif, afektif, dan konatif. Berdasarkan teori dan kerangka pemikiran yang sudah dijabarkan, berikut adalah skema penelitian yang menggambarkan alur penelitian ini:

Gambar 2. Kerangka Berpikir

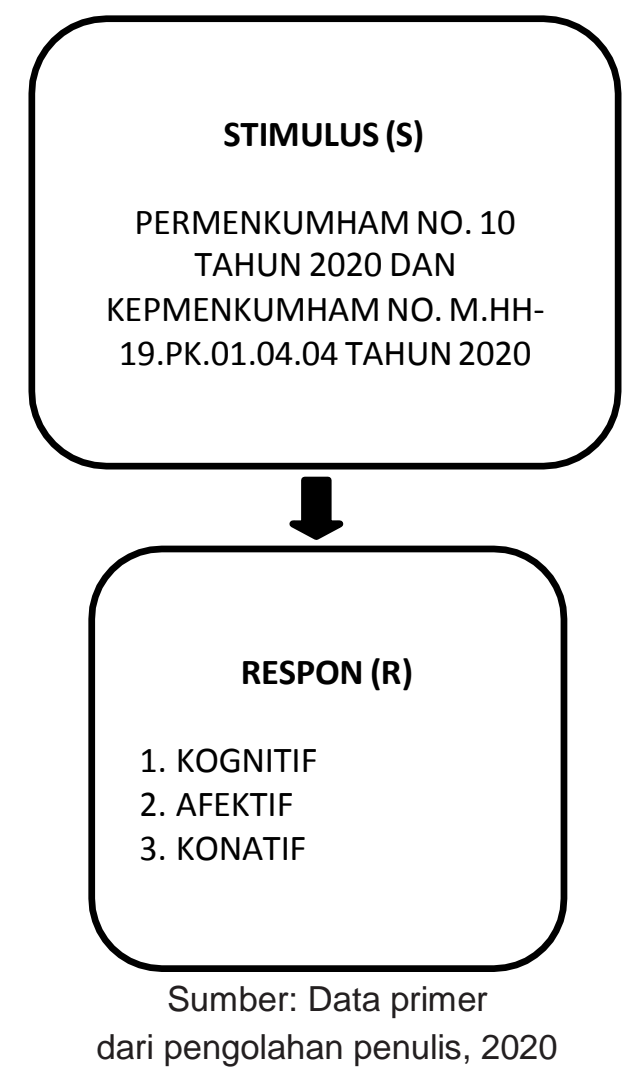


Skema penelitian diatas menunjukkan bahwa terdapat satu variabel yakni variabel independen dalam penelitian ini adalah respon masyarakat, variabel tersebut akan mengetahui stimulus dari objek penelitian ini yaitu kebijakan pembebasan narapidana dalam rangka penanggulangan corona virus covid-19.

\section{Uji Validitas}

Uji validitas digunakan untuk menyatakan bahwa sebuah instrumen penelitian dapat melakukan pengukuran terhadap sesuatu yang hendak diukur dalam sebuah penelitian. Uji validitas juga menentukan kualitas sebuah instrumen dalam sebuah riset. Pengujian validitas dilakukan terhadap empat puluh dua kuesioner melalui program SPSS dengan teknik pengujian yang menggunakan korelasi bivariate pearson (produk momen pearson). analisis ini dengan melakukan korelasi dari setiap skor item dengan skor total atau hasil penjumlahan dari keseluruhan item. Instrumen hanya akan dinyatakan valid jika $r$ hitung $\geq r$ tabel (uji 2 sisi berdasarkan sig. 0.05).

Tabel 2. Uji Validitas

\begin{tabular}{|c|c|c|c|c|}
\hline Soal & $\mathbf{N}$ & $\mathbf{r}$ hitung & $\begin{array}{c}\mathbf{r} \text { tabel }(\mathbf{s i g} . \\
\mathbf{0 , 0 5})\end{array}$ & $\begin{array}{c}\mathbf{r} \text { hitung } \mathbf{\geq} \\
\mathbf{r} \text { tabel }\end{array}$ \\
\hline 1 & 42 & 0,449 & 0,304 & Valid \\
\hline 2 & 42 & 0,854 & 0,304 & Valid \\
\hline 3 & 42 & 0,722 & 0,304 & Valid \\
\hline 4 & 42 & 0,593 & 0,304 & Valid \\
\hline 5 & 42 & 0,571 & 0,304 & Valid \\
\hline 6 & 42 & 0,424 & 0,304 & Valid \\
\hline 7 & 42 & 0,550 & 0,304 & Valid \\
\hline 8 & 42 & 0,501 & 0,304 & Valid \\
\hline 9 & 42 & 0,402 & 0,304 & Valid \\
\hline 10 & 42 & 0,616 & 0,304 & Valid \\
\hline
\end{tabular}

Sumber: analisis data angket dengan SPSS, 2020

Hasil dari analisis uji validitas seperti pada tabel diatas menunjukkan bahwa nilai koefisien korelasi dari setiap instrumen > 0,304 . dengan demikian seluruh instrumen dalam kuesioner yang telah disebarkan dapat dinyatakan valid.

\section{Uji Realibilitas}

Uji realibilitas dimaksudkan untuk menunjukkan kemampuan sebuah instrumen penelitian dalam mengukur konsep dengan stabil dan konsisten. Pengujian realibilitas kuesioner melalui program SPSS menggunakan nilai Cronbach Alpha. kuesioner hanya akan dikatakan reliabel jika sesuai dengan ketentuan yaitu nilai cronbach alpha $\geq 0,700$.

Tabel 3. Reliability Statistics

\begin{tabular}{ll} 
Cronbach's Alpha & N of Items \\
\hline ,769 & 10 \\
\hline Sumber Data: Output SPSS 25, 2020
\end{tabular}

Tampilan output dari SPSS tersebut menunjukkan bahwa respon masyarakat terhadap kebijakan pembebasan narapidana dalam rangka penanggulangan corona virus covid-19 memberikan nilai cronbach alpha sebesar $76,9 \%$ dan bisa dikatakan reliabel.

\section{Dimensi Kognitif}

Pada dimensi kognitif terdapat tiga indikator yang diteliti berupa pengetahuan (Q1), pemahaman (Q2), dan kepercayaan (Q3). Adapun hasil angket penelitian kepada masyarakat RT 022 RW 006 Dusun Punjul Desa Punjul Kecamatan Karangrejo Kabupaten Tulungagung untuk meneliti respon masyarakat terhadap kebijakan pembebasan narapidana dalam rangka penanggulangan corona virus covid-19 sebagai berikut :

Tabel 4. Dimensi Kognitif

\begin{tabular}{|l|c|c|c|c|c|c|}
\hline \multirow{2}{*}{ Skor } & \multicolumn{6}{|c|}{$\begin{array}{c}\text { Distribusi Frekuensi } \\
\text { (Dimensi Kognitif) }\end{array}$} \\
\cline { 2 - 7 } & Q1 & $\%$ & Q2 & $\%$ & Q3 & $\%$ \\
\hline $\begin{array}{l}\text { Sangat } \\
\text { Setuju }\end{array}$ & 5 & $11,9 \%$ & 4 & $9,5 \%$ & 6 & $14,3 \%$ \\
\hline Setuju & 18 & $42,9 \%$ & 6 & $14,3 \%$ & 5 & $11,9 \%$ \\
\hline $\begin{array}{l}\text { Netral/ } \\
\text { Ragu- } \\
\text { ragu }\end{array}$ & 6 & $14,3 \%$ & 10 & $23,8 \%$ & 15 & $35,7 \%$ \\
\hline $\begin{array}{l}\text { Tidak } \\
\text { Setuju }\end{array}$ & 10 & $23,8 \%$ & 17 & $40,5 \%$ & 11 & $26,2 \%$ \\
\hline
\end{tabular}




\begin{tabular}{|c|c|c|c|c|c|c|}
\hline $\begin{array}{l}\text { Sangat } \\
\text { Tidak } \\
\text { Setuju }\end{array}$ & 3 & $7,1 \%$ & 5 & $11,9 \%$ & 5 & $11,9 \%$ \\
\hline Total & 42 & $100 \%$ & 42 & $100 \%$ & 42 & $100 \%$ \\
\hline
\end{tabular}

Berdasarkan hasil angket penelitian diatas, telah didapatkan skor tertinggi pada Q1 yang mencapai kategori setuju/positif sebesar 18 responden (42,9\%), yang artinya bahwa tingkat pengetahuan masyarakat terhadap kebijakan pembebasan narapidana tinggi. Aspek kedua yaitu Q2 terdapat skor tertinggi pada kategori tidak setuju/negatif sebesar 17 responden (40,5\%), yang artinya tingkat pemahaman terhadap kebijakan pembebasan narapidana terkait alasan dikeluarkannya kebijakan tersebut dalam rangka menanggulangi penyebaran corona virus Covid-19 masih rendah. Aspek ketiga yaitu Q3 terdapat skor tertinggi pada kategori netral/ragu-ragu sebesar 15 responden $(35,7 \%)$, yang artinya tingkat kepercayaan masyarakat terhadap kebijakan yang telah ditetapkan masih diragukan. Kemudian dari ketiga aspek tersebut diambil rerataan atau mean dimana olah data yang digunakan oleh penulis melalui program SPSS dengan metode descriptive statistics sebagai berikut :

Tabel 5. Descriptive Statistics Dimensi Kognitif

\begin{tabular}{lcc|c|c|c} 
& & Q1 & Q2 & Q3 & Kognitif \\
\hline \multirow{2}{*}{$\mathrm{N}$} & Valid & 42 & 42 & 42 & 42 \\
\cline { 2 - 5 } \multicolumn{1}{c}{ Missing } & 0 & 0 & 0 & 0 \\
\hline Mean & 3,29 & 2,69 & 2,90 & 2,96 \\
\hline Std. Deviation & 1,175 & 1,158 & 1,206 &, 911 \\
\hline
\end{tabular}

Sumber Data: Output SPSS 25, 2020

Tampilan dari output SPSS tersebut menggambarkan dari 42 responden, nilai mean dimensi kognitif sebesar 2,96 yang didapatkan melalui rerata indeks aspek pengetahuan (Q1), aspek pemahaman (Q2) aspek kepercayaan (Q3) berarti terdapat rata-rata pola pikir masyarakat terhadap kebijakan pembebasan narapidana dalam rangka penanggulangan corona virus covid-19 dinilai cukup, penilaian ini akurat karena memiliki standar deviasi 0,911 lebih rendah dari nilai mean. Hal ini disebabkan oleh masyarakat di RT 022 RW 006 Dusun Punjul Desa Punjul Kecamatan Karangrejo Kabupaten Tulungagung banyak yang tidak begitu paham tentang latar belakang dan tujuan akan diberlakukannya kebijakan pembebasan narapidana sehingga menurut pengetahuan mereka melalui media apabila dibebaskan narapidana akan justru membuat penjahat bisa bebas berkeliaran dimanamana dan tingkat kriminalitas akan naik. hal ini disebabkan karena masyarakat mengetahui kebijakan pembebasan narapidana hanya sebatas mengenai alasan diputuskannya kebijakan tersebut untuk memangkas beban pengeluaran negara terkait penanggulangan pandemi corona, dan mereka tidak memahami fungsi kebijakan tersebut dikeluarkan seperti sulitnya physical distancing di Lapas, LPKA, Rutan serta terkait asimilasi yang ketika dilakukan pembauran ke masyarakat akan rentan terhadap penularan covid-19, kemudian tingkat kepercayaan masyarakat masih diragukan karena hanya sebagian orang yang mengerti tujuan sebenarnya dari dikeluarkan kebijakan tersebut. ${ }^{24}$

\section{Dimensi Afektif}

Pada dimensi afektif terdapat empat indikator yang diteliti berupa Penerimaan (Q4), Sikap (Q5), dan Partisipasi (Q6), Penilaian (Q7). Adapun hasil angket penelitian kepada masyarakat RT 022 RW 006 Dusun Punjul Desa Punjul Kecamatan Karangrejo Kabupaten Tulungagung untuk meneliti respon masyarakat terhadap kebijakan pembebasan narapidana dalam rangka penanggulangan corona virus covid-19 sebagai berikut:

24 "Wawancara Dengan Solikin,Selaku Ketua RT 022 Dusun Punjul," 2020. 
Tabel 6. Dimensi Afektif

\begin{tabular}{|l|c|c|c|c|c|c|c|c|}
\hline \multirow{2}{*}{ SKOR } & \multicolumn{7}{|c|}{ Distribusi Frekuensi (Dimensi Afektif) } \\
\cline { 2 - 9 } & Q4 & $\%$ & Q5 & $\%$ & Q6 & $\%$ & Q7 & $\%$ \\
\hline $\begin{array}{l}\text { Sangat } \\
\text { Setuju }\end{array}$ & 7 & $16,7 \%$ & 5 & $11,9 \%$ & 4 & $9,5 \%$ & 5 & $11,9 \%$ \\
\hline Setuju & 12 & $28,6 \%$ & 3 & $7,1 \%$ & 15 & $35,7 \%$ & 3 & $7,1 \%$ \\
\hline $\begin{array}{l}\text { Netral/ } \\
\text { Ragu- } \\
\text { ragu }\end{array}$ & 14 & $33,3 \%$ & 4 & $9,5 \%$ & 10 & $23,8 \%$ & 4 & $9,5 \%$ \\
\hline $\begin{array}{l}\text { Tidak } \\
\text { Setuju }\end{array}$ & 7 & $16,7 \%$ & 22 & $52,4 \%$ & 9 & $21,4 \%$ & 22 & $52,4 \%$ \\
\hline $\begin{array}{l}\text { Sangat } \\
\text { Tidak } \\
\text { Setuju }\end{array}$ & 2 & $4,8 \%$ & 8 & $19,0 \%$ & 4 & $9,5 \%$ & 8 & $19.0 \%$ \\
\hline Total & 42 & $100 \%$ & 42 & $100 \%$ & 42 & $100 \%$ & 42 & $100 \%$ \\
\hline
\end{tabular}

Sumber: Analisis Data Skor

Angket Penelitian, 2020

Berdasarkan hasil angket penelitian, aspek yang pertama yaitu Q4 didapatkan nilai tertinggi pada kategori netral/ragu-ragu sebesar 14 responden (33,3\%), artinya tingkat penerimaan terhadap dikeluarkannya kebijakan pembebasan narapidana dinilai netral atau masih diragukan. Kedua Q5 didapatkan nilai tertinggi pada kategori tidak setuju/ negatif sebesar 22 responden $(52,4 \%)$, yang artinya sikap masyarakat terhadap kebijakan terdapat penolakan. Aspek ketiga Q6 didapatkan nilai tertinggi pada kategori setuju sebesar 15 responden $(35,7 \%)$, yang artinya partisipasi masyarakat terhadap kebijakan tinggi. Aspek yang keempat adalah Q7 didapatkan nilai tertinggi pada kategori tidak setuju/ negatif sebesar 22 responden $(52,4 \%)$, berarti penilaian masyarakat terhadap kebijakan rendah atau dinilai tidak efektif. Kemudian dari keempat aspek tersebut diambil rerataan melalui program SPSS dengan metode descriptive statistics sebagai berikut :

Tabel 7. Descriptive Statistics Dimensi Afektif

\begin{tabular}{|c|c|c|c|c|c|c|}
\hline & Q4 & Q5 & Q6 & Q7 & Afektif \\
\hline \multirow[t]{2}{*}{$\mathrm{N}$} & Valid & 42 & 42 & 42 & 42 & 42 \\
\hline & Missing & 0 & 0 & 0 & 0 & 0 \\
\hline \multicolumn{2}{|c|}{ Mean } & 3,36 & 2,40 & 3,14 & 2,40 & 2,83 \\
\hline \multicolumn{2}{|c|}{$\begin{array}{l}\text { Std. } \\
\text { Deviation }\end{array}$} & 1,100 & 1,231 & 1,160 & 1,231 & ,867 \\
\hline
\end{tabular}

Sumber Data: Output SPSS 25, 2020
Tampilan dari output SPSS tersebut menggambarkan bahwa dari 42 responden yang berhasil mengisi data atau valid, nilai mean dari dimensi afektif sebesar 2,83 yang berarti rata-rata watak perilaku masyarakat terhadap kebijakan pembebasan narapidana dinilai cukup. Data tersebut merupakan hasil rerata dari indeks aspek penerimaan yang cukup, indeks aspek sikap yang kurang, indeks aspek partisipasi yang cukup, serta indeks aspek penilaian yang kurang. Kemudian standar deviasi sebesar 0,867 menunjukkan hasil analisis melalui mean akurat karena rentang variasi data instrumen rendah dan angka tersebut lebih kecil dari angka mean. Hal ini disebabkan oleh sikap masyarakat yang menolak kebijakan dan masyarakat menilai kebijakan tersebut tidaklah efektif karena daripada membuat ulah diluar narapidana lebih baik produktif didalam lembaga pemasyarakatan guna membuat masker gratis hal ini dipicu oleh media yang selalu memviralkan aksi kejahatan yang dikaitkan dengan kebijakan seolah-olah kejahatan itu terjadi dari efek dikeluarkannya kebijakan pembebasan narapidana, padahal dari 38,822 narapidana hanya 39 orang yang berulah kembali. Kemudian masyarakat masih ragu-ragu dalam menerima kebijakan tersebut dikarenakan pemberitaan media yang selalu membesar-besarkan terhadap maraknya kejahatan pada masa pandemi corona sehingga masyarakat melakukan partisipasi terkait kewaspadaan terhadap kejahatan baru yang tinggi. ${ }^{25}$

\section{Dimensi Konatif}

Pada dimensi konatif yang merupakan respon ketiga yang biasa disebut respon psikomotorik dimana respon yang memiliki keterkaitan erat dengan perilaku seseorang yang meliputi tindakan, tingkah laku, kebiasaan. Kemudian pada dimensi ini terdapat tiga indikator yang diteliti yaitu,

25 Ibid 
pertama adalah perilaku nyata yang terdapat pada item kuisioner yang ke delapan (Q8), indikator kedua adalah tindakan yang terdapat pada item kuisioner yang ke sembilan (Q9), dan indikator ketiga adalah kebiasaan yang terdapat pada item kuisioner yang ke sepuluh (Q10). Adapun hasil angket penelitian kepada masyarakat RT 022 RW 006 Dusun Punjul Desa Punjul Kecamatan Karangrejo Kabupaten Tulungagung untuk meneliti respon masyarakat terhadap kebijakan pembebasan narapidana dalam rangka penanggulangan corona virus covid-19 sebagai berikut :

\section{Tabel 8. Dimensi Konatif}

\begin{tabular}{|l|c|c|c|c|c|c|}
\hline \multirow{2}{*}{ Skor } & \multicolumn{5}{|c|}{ Distribusi Frekuensi (Dimensi Konatif) } \\
\cline { 2 - 7 } & $\mathbf{Q 8}$ & $\%$ & $\mathbf{Q 9}$ & $\%$ & $\mathbf{Q 1 0}$ & $\%$ \\
\hline $\begin{array}{l}\text { Sangat } \\
\text { Setuju }\end{array}$ & 17 & $40,5 \%$ & 13 & $31,0 \%$ & 11 & $26,2 \%$ \\
\hline Setuju & 15 & $35,7 \%$ & 22 & $52,4 \%$ & 12 & $28,6 \%$ \\
\hline $\begin{array}{l}\text { Netral/ } \\
\text { Ragu-ragu }\end{array}$ & 5 & $11,9 \%$ & 3 & $7,1 \%$ & 7 & $16,7 \%$ \\
\hline $\begin{array}{l}\text { Tidak } \\
\text { Setuju }\end{array}$ & 3 & $7,1 \%$ & 2 & $4,8 \%$ & 10 & $23,8 \%$ \\
\hline $\begin{array}{l}\text { Sangat } \\
\text { Tidak } \\
\text { Setuju }\end{array}$ & 2 & $4,8 \%$ & 2 & $4,8 \%$ & 2 & $4,8 \%$ \\
\hline Total & 42 & $100 \%$ & 42 & $100 \%$ & 42 & $100 \%$ \\
\hline
\end{tabular}

Sumber: Analisis Data Skor

Angket Penelitian, 2020

Berdasarkan hasil angket penelitian Aspek yang pertama pada dimensi konatif yaitu perilaku nyata (Q8) terdapat nilai tertinggi pada kategori sangat setuju sebesar 17 responden atau $40,5 \%$, artinya dampak dari kebijakan pembebasan narapidana membuat kecenderungan untuk melakukan sesuatu. Kedua pada aspek Tindakan (Q9) terdapat nilai tertinggi pada kategori setuju/ positif sebesar 15 responden atau 35,7\%, artinya dampak dari kebijakan pembebasan narapidana membuat masyarakat untuk bertindak. Ketiga pada aspek kebiasaan (Q10) terdapat nilai tertinggi pada kategori setuju sebesar 12 responden atau 28,6\% kemudian pada kategori sangat setuju sebesar 11 responden atau $26,2 \%$, yang berarti bahwa dampak dari kebijakan pembebasan narapidana membuat masyarakat memiliki kebiasaaan baru. Selanjutnya dari ketiga aspek tersebut diambil rerataan melalui program SPSS dengan metode descriptive statistics sebagai berikut :

Tabel 9. Descriptive Statistics Dimensi Konatif

\begin{tabular}{llc|c|c|c} 
& & Q8 & Q9 & Q10 & Konatif \\
\hline $\mathrm{N}$ & 42 & 42 & 42 & 42 \\
\cline { 2 - 6 } & Valid & 42 & 0 & 0 & 0 \\
\hline Mean & 4,00 & 4,00 & 3,48 & 3,83 \\
\hline Std. Deviation & 1,126 & 1,012 & 1,254 &, 893 \\
\hline
\end{tabular}

Sumber Data: Output SPSS 25, 2020

Tampilan dari output SPSS tersebut menggambarkan dari 42 responden yang berhasil mengisi data atau valid, nilai mean dimensi konatif sebesar 3,83 berarti kecenderungan berperilaku masyarakat terhadap adanya kebijakan pembebasan narapidana dalam rangka penanggulangan corona virus covid-19 dinilai baik. Data tersebut merupakan hasil dari rerata indeks aspek perilaku nyata yang baik, indeks aspek tindakan yang baik, dan indeks aspek kebiasaan yang baik. Menurut hasil instrumen penelitian dapat disimpulkan bahwa hal ini disebabkan oleh dampak dari kebijakan pembebasan narapidana yang membuat masyarakat melakukan perilaku waspada, tindakan-tindakan seperti penjagaan dan membuat kebiasaan baru seperti digencarkannya ronda bergilir sebagai antisipasi tindak kejahatan di RT 022 RW 006 Dusun Punjul Desa Punjul Kecamatan Karangrejo Kabupaten Tulungagung.

Hasil Analisis Respon Masyarakat Terhadap Kebijakan Pembebasan Narapidana Dalam Rangka Penganggulangan Corona Virus Covid-19

Hasil analisis respon diperoleh dari kesimpulan rerata dari ketiga dimensi respon yang sebelumnya telah dijelaskan menurut Steven M. Chafferespon bahwa respon dibedakan menjadi 3 (tiga) bagian 
yaitu dimensi kognitif (cognitive), dimensi afektif (affective), dimensi konatif (conative). Respon masyarakat terhadap kebijakan pembebasan narapidana yang kemudian data yang didapatkan diolah melalui program komputer yaitu Software SPSS. Adapun data yang dihasilkan dengan metode descriptive statistics sebagai berikut :

Tabel 10. Descriptive Statistics Respon Kognitif Afektif Konatif Respon

\begin{tabular}{l|c|c|c|c|c}
\hline $\mathrm{N}$ & Valid & 42 & 42 & 42 & 42 \\
\cline { 2 - 6 } \multicolumn{1}{c}{ Missing } & 0 & 0 & 0 & 0 \\
\hline Mean & 2,96 & 2,83 & 3,83 & 3,20 \\
\hline Std. Deviation &, 911 &, 867 &, 893 &, 673 \\
\hline
\end{tabular}

Sumber Data: Output SPSS 25, 2020

Berdasarkan dari output SPSS tersebut dapat dilihat rerataan pada kolom mean dimensi kognitif sebesar 2,96, dimensi afektif sebesar 2,83, dan dimensi konatif sebesar 3,83. Disimpulkan respon yang merupakan hasil overall ketiga dimensi tersebut menghasilkan nilai mean sebesar 3,20 dan standar deviasi 0,673 yang artinya data mean akurat yang dibuktikan dengan nilai rata-rata respon lebih besar daripada standar deviasi. Jadi respon masyarakat terhadap kebijakan pembebasan narapidana dalam rangka penanggulangan covid-19 dinilai cukup namun masih perlu diharuskan diberikan pemahaman terkait kebijakan pembebasan narapidana dan bahkan terkait tugas pemasyarakatan.

\section{PENUTUP}

\section{Kesimpulan}

Respon masyarakat terhadap kebijakan pembebasan narapidana dalam rangka penanggulangan penyebaran corona virus Covid-19 di Dusun Punjul Desa Punjul Kecamatan Karangrejo Kabupaten Tulungagung untuk menjawab permasalahan dalam penelitian berdasarkan analisis data yang di dapatkan, maka hasil dari penelitian yang diperoleh adalah terdapat respon masyarakat RT 022 RW 006 Dusun Punjul Desa Punjul Kecamatan Karangrejo
Kabupaten Tulungagung yang cukup dalam merespon kebijakan pembebasan narapidana guna penanggulangan dan pencegahan corona virus Covid-19 dalam Rumah Tahanan Negara, Lembaga Pemasyarakatan, Lembaga Pembinaan Khusus Anak, hal ini disebabkan dari segi kognitif hasil analisis menunjukkan bahwa masyarakat mempunyai potensi intelektual yang cukup terkait adanya kebijakan pembebasan narapidana sebagai upaya penanggulangan corona virus covid-19 yang dimana masyarakat hanya mengetahui sebatas adanya kebijakan, dan tidak memahami fungsi dari diterapkannya kebijakan tersebut dan kepercayaan yang masih diragukan. Kemudian disebabkan dari segi afektif menunjukkan bahwa masyarakat mempunyai watak perilaku yang cukup terkait adanya kebijakan pembebasan narapidana sebagai upaya penanggulangan corona virus covid-19 yang dimana masyarakat masih ragu-ragu dalam menerima kebijakan tersebut, dan partisipasi masyarakat yang ikut waspada dalam menjaga keamanan kampung sebagai wujud sikap daya dukung dan penilaian terhadap efektivitas kebijakan rendah. Terakhir disebabkan oleh dimensi konatif, dari hasil analisis menunjukkan bahwa masyarakat mempunyai perilaku tindakan yang baik dalam merespon kebijakan pembebasan narapidana seperti perilaku waspada, melakukan penjagaan hingga kebiasaan baru gilir jaga.

\section{Saran}

Berdasarkan kesimpulan penelitian ini yang telah disampaikan sebelumnya, maka peneliti mengajukan rekomendasi atau saran yaitu dengan memberikan edukasi kepada masyarakat diharapkan bisa digencarkan supaya masyarakat dapat mengenal pemasyarakatan lebih jauh melalui media sosial, humas yang berperan aktif, Menciptakan program melek pemasyarakatan berupa banner edukasi yang dipasang di tempat publik, iklan pengetahuan terkait 
pemasyarakatan, agar lebih dekat dengan masyarakat dan Sosialisasi dengan terjun ke masyarakat langsung, sehingga kebijakan pembebasan narapidana atau kebijakan lain terkait hunian LAPAS, LPKA, dan RUTAN bisa dipahami oleh masyarakat, karena hal yang paling mendasar saat ini pengetahuan masayarakat tentang pemasyarakatan sama dengan pemenjaraan dan tak mengenal asimilasi maupun integrasi yang saat ini menjadi polemik dibebaskannya narapidana melalui program tersebut dalam rangka penanggulangan Covid-19.

\section{UCAPAN TERIMA KASIH}

Peneliti ucapkan terimakasih kepada seluruh pihak yang telah membantu dalam menyelesaikan penelitian ini khususnya kepada Warga setempat RT 022 RW 06 Dusun Punjul Desa Punjul Kecamatan Karangrejo Kabupaten Tulungagung beserta Ketua RT yang telah membantu memberikan informasi dan data selama pelaksanaan penelitian.

\section{DAFTAR PUSTAKA}

Al-Osail, Aisha M., and Marwan J. Al-Wazzah. "The History and Epidemiology of Middle East Respiratory Syndrome Corona Virus." Multidisciplinary Respiratory Medicine 12, no. 1 (2017).

B. Aubrey Fisher. Teori-Teori Komunikasi : Perspektif Mekanistis, Psikologis, Interaksional, Dan Pragmatis. Edited by Rakhmat Jalaludin. Bandung: Remadja Karja, 1986.

Fitri, Wanda. Dan Perilaku "Perempuan Kritis Peran Stigma Sosial Pada Kasus Residivis Perempuan." Kafa ah: Journal of Gender Studies 7, no. 1 (2017): 67.

Jazuli, Ahmad. "Pembentukan Satuan Kerja Baru Pemasyarakatan Sebagai Solusi Alternatif Mengatasi Overcrowded." Jurnal IImiah Kebijakan Hukum (2021).

Kriyantono, Rachmat. Teknik Praktis Riset Komunikasi. Prenada Media, 2006.
Pebriana, Lila Afrida. "Kontra Masyarakat Terhadap Meningkatnya Kriminalitas Pasca Asimilasi Narapidana Dampak Covid-19." Legal Standing : Jurnal IImu Hukum 4, no. 2 (2020).

Rahayu, Siti Kurnia. Perpajakan Indonesia: Konsep Dan Aspek Formal. Yogyakarta: Graha IImu, 2010.

Rakhmat, Jalaluddin. Metode Penelitian Komunikasi. Bandung: Remaja Rosdakarya. Bandung: PT Remaja Rosdakarya, 1999.

Rohman, Asep Taufik. "Implementasi Kebijakan Melalui Kualitas Pelayanan Penerimaan Pajak Daerah Dan Implikasinya Terhadap Kepuasan Masyarakat Di Dinas Pendapatan Kabupaten Kuningan." Bandung: Universitas Pasundan, 2016.

Rohman, Fathur. "38.822 Napi Dan Anak Dikeluarkan Dari Lapas Cegah Pandemi COVID-19." Antaranews.

S.Eko Putro Widoyoko. Evaluasi Program Pembelajaran. Yogyakarta: Pustaka Belajar, 2009.

Sanusi, Ahmad. "Aspek Layanan Kesehatan Bagi Warga Binaan Pemasyarakatan Dan Tahanan Di Lembaga Pemasyarakatan." Jurnal Ilmiah Kebijakan Hukum 10, no. 1 (2016): 1-29.

Sugiyono. Metode Penelitian Administrasi. Bandung: CV Alfabeta, 2002.

- Metode Penelitian Kuantitatif, Kualitatif, Dan $R \& D$. Bandung: Alfabeta, 2016.

Sulasmono, Bambang Suteng. "Respons Masyarakat Desa Terhadap Pembangunan Industri Besar Kasus Desa Hardjosari, Kecamatan Bawen, Kabupaten Semarang, Jawa Tengah." Universitas Kristen Satya Wacana, 1994.

Taneko, Soleman B. Sistem Sosial Indonesia. Jakarta: Fajar Agung, 1994.

Whitworth, Jimmy. "COVID-19: A Fast Evolving Pandemic." Transactions of the Royal Society of Tropical Medicine and Hygiene 114, no. 4 (2020): 227-228. 
Kepmenkes No. Hk.01.07/Menkes/328/2020

Panduan Pencegahan Dan Pengendalian Corona Virus Disease 2019 (Covid-19) Di Tempat Kerja Perkantoran Dan Industri Dalam Mendukung Keberlangsungan Usaha Pada Situasi Pandemi, Republik Indonesia, 2020.

Kepmenkes No. HK.01.07/

MENKES/382/2020 Tentang Protokol Kesehatan Bagi Masyarakat Di Tempat Dan Fasilitas Umum Dalam Rangka Pencegahan Dan Pengendalian Corona Virus Disease 2019 (Covid-19), Republik Indonesia, 2020.

Permenkes No. 9 Tahun 2020 Tentang Pedoman Pembatasan Sosial Berskala Besar Dalam Rangka Percepatan Penanganan Corona Virus Disease 2019 (Covid-19), Republik Indonesia, 2020

Kepmenkumham No. M.HH-19.PK.01.04.04 Tahun 2020 tentang Pengeluaran dan Pembebasan Narapidana dan Anak, Republik Indonesia, 2020.

Permenkumham No. 10 Tahun 2020 Tentang Syarat Pemberian Asimilasi Dan Hak Integrasi Bagi Narapidana Dan Anak Dalam Rangka Pencegahan Melalui Program Asimilasi Dan Penanggulangan Penyebaran Covid-19. Republik Indonesia, 2020.

"Wawancara Dengan Solikin,Selaku Ketua RT 022 Dusun Punjul," 2020. 
JIKH Vol. 15, No. 2, Juli 2021: 165-180

p-ISSN: 1978-2292 e-ISSN: 2579-7425

\section{HALAMAN KOSONG}

